Historic, Archive Document

Do not assume content reflects current scientific knowledge, policies, or practices. 


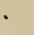




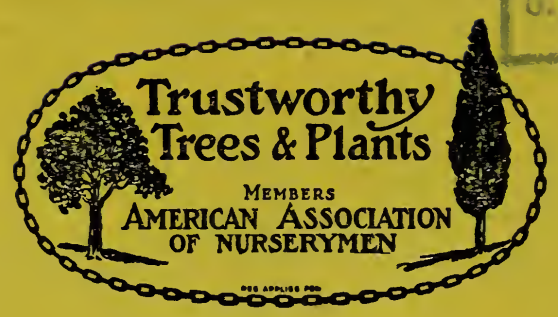

\section{Price List of}

\section{ROOT'S NURSERIES}

\section{Manheim, R. D. 1 Pa,}

\section{APPLES-2 years}

Each Per10 Per100

Extra size, 6 to 7 feet. . $\$ 1.50 \$ 12.50$

First Class, 5 to 6 feet.... $1.25 \quad 10.00 \$ 90.00$

First Class, 4 to 5 feet.... $1.00 \quad 8.00 \quad 70.00$

First Class, 3 to 4 feet... $\quad .75 \quad 6.00 \quad 50.00$

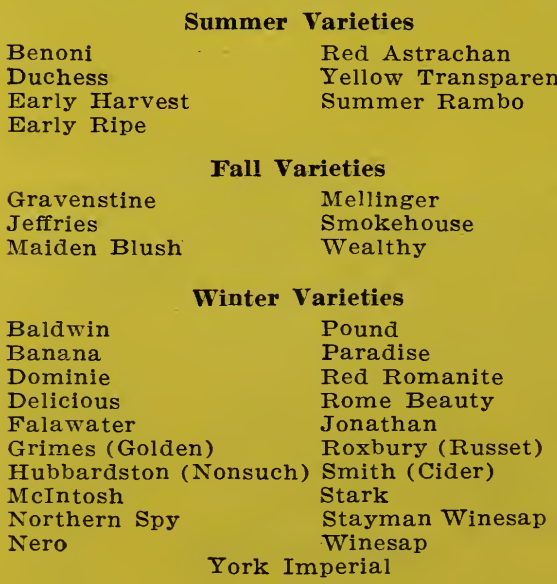

\section{CRAB APPLES}

Same prices as apples.

Hyslop

Transcendent Yellow Siberian

\section{PEACHES}

Each Per10 Per100

Extra size, $5 \frac{1 / 2}{2}$ to 7 feet. $\$ 1.00 \$ 8.50$

First Class, $4 \frac{1 / 2}{2}$ to 6 feet. $.85 \quad 7.50 \quad \$ 70.00$

First Class, 4 to 5 feet... $\quad .75 \quad 6.50 \quad 60.00$

First Class, 3 to 4 feet... $.60 \quad 5.50 \quad 50.00$

Variety Arranged in Order of Ripening (W, White; Y, Yellow)

Sneed, W

Greensboro, W

Carman, W

Champion, W

Belle of Georgia, W

Captain Ede, $Y$

Globe, $Y$

Elberta, $Y$

Niacara, $\mathbf{Y}$

Hale, Y

Late Crawfords, $Y$

Susquehannah, Y
Mathews, Y
Old Mixon, W
Chairs, Y
Fitzgerald, Y
Fox, W
Stump, W
Smock, Y
Salway, Y
Iron Mountain, W

Bilyeu's Late October, W

\section{PEARS}

Each Per 10

Extra Size, 6 to 7 feet........\$1.50 \$12.50

First Class, 5 to 6 feet.......... $1.25 \quad 10.00$

Dwarf Pear ...................... $1.25 \quad 10.00$

Varieties

Wilder Early

Clapp's Favorite

Bartlett

Seckel

Flemish Beauty

Sheidon

Lawrence

Duchess 


\section{CHERRIES}

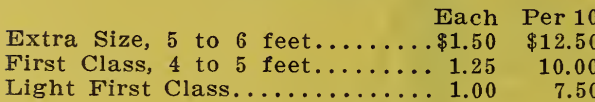

\section{Sweet Varieties}

Black Tartarian Governor Wood

Napoleon

Schmidt's

Yellow Spanish

Windsor

Mercer

\section{Sour Varieties}

Early Richmond Iarge Montmorency English Morello

\section{PLUMS}

Each Per 10

Extra Size, 5 to 6 feet......\$1.50

First Class, 4 to 5 feet........ 1.25

$\$ 12.50$

10.00

Light First Class............. 1.00

7.50

\section{Varieties}

$\begin{array}{ll}\text { Abundance } & \text { Bradshaw } \\ \text { Burbank } & \text { German Prune } \\ \text { Ogon } & \text { Wickson } \\ \text { Red June } & \text { Ye!low Egg } \\ \text { Satsuma } & \text { Niagara } \\ \text { Imperial Gage } & \text { !talian Prune } \\ \text { Lombard } & \text { Climax }\end{array}$

October Purpie

\section{QUINCES}

Each Per 10

Extra Size, 4 to 5 feet.......\$1.50 $\$ 12.50$

First Class, 3 to 4 feet......... $1.25 \quad 10.00$

\section{Varieties}

Bourgeat

Meech's Prolific

Champion

Orange

Rea's Mammoth

\section{APRICOTS}

Extra Size, \$1.50 each. First Class, \$1.25 Early Golden, Harris, Moorpark, Alexis.

\section{SMALL FRUITS}

Raspberries, $75 \mathrm{c}$ per $10 ; \$ 5.00$ per 100 . Cuthbert, Cumberland, St. Regis.

Blackberries, $75 \mathrm{c}$ per $10 ; \$ 5.00$ per 100 . Eldorado, Blowers, Taylor.

Currants. Strong Plants. $40 \mathrm{c}$ each; $\$ 3.50$ per 10. Fays Prolific, White Grape, Cherry, Fresident Wilder.

Gooseberries. Strong Plants. $40 \mathrm{c}$ each; $\$ 3.50$ per 10. Downing, Smith, Red Jacket, Houghton, Industry.

Rhubarb. $15 \mathrm{c}$ each; $\$ 1.25$ per 10 .

Asparagus. Palmetto. Strong 2 year roots. $25 \mathrm{c}$ per $10 ; \$ 1.50$ per $100 ; \$ 10.00$ per 1000 . 3 year extra heavy, $\$ 2.00$ per 100 .

Strawberries. $25 \mathrm{c}$ per $10 ; \$ 1.50$ per $100 ; \$ 10.00$ per 1000. Haveriand, Parsons, Bismark, Sample, Buster, Uncle Jim, Senator.

Grapes. 2 year strong. $40 \mathrm{c}$ each; $\$ 3.50$ per 10. Brighton, Concord, Worden, Niagara, Moor's Early.

\section{NUT TREES}

\section{Hardy Northern Grown}

Each Per 10

Pecans, seedling trees, 3 to $4 \mathrm{ft} . . \$ 1.00 \$ 8.50$

Pecans, seedling trees, 4 to $5 \mathrm{ft} . .1 .25 \quad 10.00$

Pecans, budded, 3 to $5 \mathrm{ft} \ldots \ldots \ldots .1 .75 \quad 15.00$

Pecans, budded, 4 to $5 \mathrm{ft} . \ldots \ldots 2.00 \quad 17.00$

Engish Walnut, seedlings, 3 to 4

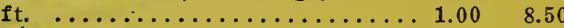

Engiish Walnut, budded, 3 to $4 \mathrm{ft}$. 1.7515 .00

English Walnut, budded, 4 to $5 \mathrm{ft} .2 .00 \quad 17.50$

Black Walnut, seedlings, 3 to $4 \mathrm{ft}$. $.50 \quad 4.50$

Black Walnut, grafted, 3 to $4 \mathrm{ft} .1 .50 \quad 12.00$

Black Walnut, grafted, 4 to $5 \mathrm{ft} .1 .75 \quad 15.00$

Japan Walnut, seedlings, 3 to $4 \mathrm{ft}$. $\quad .50 \quad 4.50$

Japan Walnut, seedlings, 4 to $5 \mathrm{ft}$. $.70 \quad 6.50$

MULRERRY-Downing, New Amer-

ican, 4 to $6 \mathrm{ft}$............\$1.00 each

\section{SHADE AND ORNAMENTAL TREES}

Each Per 10

Ash, White, 8 to $10 \mathrm{ft} . \ldots \ldots \ldots \$ 1.50$

Birch, White, 8 to $10 \mathrm{ft} \ldots \ldots \ldots 1.50$

Birch, Cutleaf Weeping, 6 to $8 \mathrm{ft}$. 2.00

Birch, Cutleaf Weeping, 8 to $10 \mathrm{ft} .2 .50$

Becch, Purple, 4 to $5 \mathrm{ft} . \ldots \ldots \ldots 2.50$

Catalpa, Speciosa, 6 to $8 \mathrm{ft} \ldots \ldots .1 .00$

Catalpa, Bungei, Umbrella tree, 4 to $6 \mathrm{ft} \ldots \ldots \ldots \ldots \ldots \ldots \ldots \ldots$

Cata!pa, Bungei, Ümbrella tree, 6 to $8 \mathrm{ft} \ldots \ldots \ldots \ldots \ldots \ldots \ldots 2.00$

Dogwood, White flowering, 3 to 4 ft. .................. 1.00

Dogwood, Red flowering, 2 to $4 \mathrm{ft}$. 1.75

Elm, American, 8 to $10 \mathrm{ft} \ldots \ldots .1 .75$

Linden, European, 10 to $12 \mathrm{ft} \ldots 3.00$

Linden, American, 8 to $10 \mathrm{ft} \ldots .2 .50$

Maple, Norway, 6 to $8 \mathrm{ft} \ldots \ldots \ldots 1.75$

Maple, Norway, 8 to $10 \mathrm{ft} . \ldots .22 .00$

Maple, Norway, 10 to $12 \mathrm{ft} \ldots \ldots 2.50$

Maple, Norway, 12 to $14 \mathrm{ft}$..... 3.50

Maple, Schwedleri, 10 to $12 \mathrm{ft}$... 3.50

Maple, Silver, 8 to $10 \mathrm{ft} \ldots \ldots \ldots 1.50$

Maple, Silver, 10 to $12 \mathrm{ft} \ldots \ldots \ldots .1 .75$

Maple, Sugar, 8 to $10 \mathrm{ft} \ldots \ldots \ldots 2.00$

Maple, Wier's Cutleaf, 10 to $12 \mathrm{ft}$. 2.25

Maple, Japan, Blood Leaf, 18 in. 3.50

Maple, Japan, Blood Leaf, $2 \mathrm{ft} . .5 .00$

Maple, Japan, Red Fern Leaf, 2 ft 5.00

Magnolia, White, Pink and Purple Flowering, 2 to $3 \mathrm{ft} \ldots \ldots 4.00$

Oalk, Pin, 8 to $10 \mathrm{ft} \ldots \ldots \ldots \ldots 3.50$

Oak, Red, 8 to $10 \mathrm{ft} \ldots \ldots \ldots \ldots \ldots 3.50$

Oriental Plane (Sycamore), 8 to $10 \mathrm{ft} . \ldots \ldots \ldots \ldots \ldots \ldots \ldots \ldots \ldots \ldots . \ldots \ldots$

Oriental Plane (Sycamore), 10 to

$12 \mathrm{ft} . \ldots \ldots \ldots \ldots \ldots \ldots \ldots \ldots 2.25$

Poplar, Lombardy, $10 \mathrm{ft} \ldots \ldots \ldots .1 .25$

Poplar, Lombardy, 10 to $12 \mathrm{ft} . \ldots 1.50$

Salisburia or Gingko, 8 to $10 \mathrm{ft.} .2 .00$

Tulip Tree, 8 to $10 \mathrm{ft} . \ldots \ldots \ldots 2.00$

Ask for prices on larger trees and large orders.

\section{WEEPING TREES}

15.00

20.00

10.00

14.00

17.50

22.50

12.50

15.00

Cutleaf Weeping Birch. See Birch

Each

Tea's Weeping Mulberry, on 4 to $6 \mathrm{ft}$. stem, 2 year heads............ \$2.75

villow, Babylonian, 8 to $10 \mathrm{ft} \ldots \ldots \ldots \ldots .25$ 


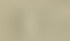

\section{soyrt}

\section{(1)}

$n^{2}$

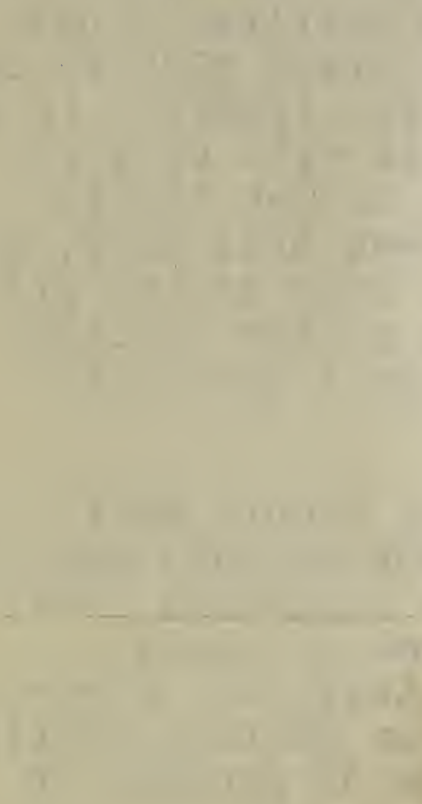

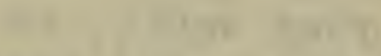

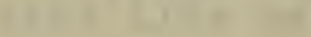

11

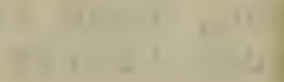

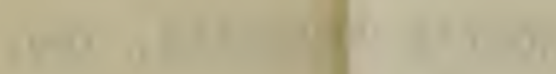




\section{ROOT'S NURSERIES, INC.}

Manheim, R. D. No. 1, Pa.

Dear Friend:-

February, 1921

This time of year we plan for the coming season, what shall we plant, or what improvements will we make? This year it will be well to look both ways before buying, will a dollar invested now be worth more or less to us a year from now? We all agree there are many things that are never worth more than at the time we buy them. There are however some things that do increase in value from year to year, this class of stock is offered in enclosed price list. You may decide to wait until prices are lower, but can you afford to wait? Fruit trees do not come into bearing in one year. Experienced growers have agreed that Apple trees planted in orchard increase in value fully $\$ 1.00$ per year. For example, if you pay $\$ 1.00$ now for an apple tree, a year from now it will be worth $\$ 1.00$ plus the cost of the tree at that time. It is not likely that we will be giving apple or any other trees away next year, so you can figure that you will be ahead in the game even if the price seems high. If you plant in larger quantity than priced on list, send your list of wants for special prices, we make a specialty of supplying large planters.

Some Nurserymen spend lots of money telling people what wonderful trees and plants they have, there is none as good as their's. We find it nore satisfactory to let our customers boost our stock, and are taking this opportunity to thank our many customers and friends for their valuable support they have given us along this line. Frequently we get letters from parties stating, you have been recommended to us by certain persons as growers of reliable nursery stock.

Will be pleased to hear from you regarding your wants, be it one tree, shrub, or one thousand. If you desire, we will help you with your planting plans free of charge.

We are improving our service wherever we can, have recently secured private telephone line, which is giving much better satisfaction than the former service.

Yours for success,

Cut this out, telephone calls ROOT'S NURSERIES, Ino. $\begin{array}{lll}\text { United Telephone } & 10 \text { E. Petersburg } \\ \text { Bell } & 43 \mathrm{M} \text { Landisville }\end{array}$ Root's Nurseries, Inc. 
Price List of ROOT'S NURSERIES

\section{EVERGREENS}

Each Per 10

Arborvitae, American, 12 to 18 in. $\$ .75 \$ 6.00$

Arborvitae, American, 18 to 24 in. 1.00

Arborvitae, American, 2 to $3 \mathrm{ft}$.. 1.50

Arbervitae, American, 3 to $4 \mathrm{ft}$.. 2.00

Arborvitae, Compacta, 12 to 18 in. 1.75

Arborritae, Compacta, 18 to 24 in. 2.00

Arborvitae, Pyramidal, 2 to $3 \mathrm{ft.} .2 .25$

Arborvitae, Pyramidal, 3 to $4 \mathrm{ft}$.. 3.00

Arborvitae, Globe, very dwarf, 12

to 15 in.................. 1.75

Arborvitae, Geo. Peabody, golden,

18 to 24 in...............25

Arbervilae, Siberian, 18 to 24 in. 1.75

Arborvitae, Siberian, 2 to $3 \mathrm{ft}$... 2.50

Arborvitae, Rosenthali, 18 in.... 2.00

Arborvitae, Tom Thumb, 12 to 15

in. ....................... 1.50

Arborvitae, Hovey's Golden, 15 to

18 in..................... 1.50

Arborritae, Hovey's Golden, 18 to

24 in. ....................... 2.50

Boxwood, Tree Box, 12 to 15 in.. 1.50

Boxwood, Pyramidal, $3 \mathrm{ft} . \ldots \ldots .5 .00$

Boxwood, Pyramidal, $4 \mathrm{ft} . . . \ldots 6.00$

Boxwood, Globe Shaped, 20 in.

high, 20 in. wide.......... 6.00

Boxwood, Dwarf Box, for edging,

4 to 6 in...................... .30

Cryptomeri Japonica, 4 to $5 \mathrm{ft} \ldots 6.00$

Fir, Ba!sam, 15 to 18 in....... 1.75

Fir, Nordmans, 18 in.......... 2.50

Fir, Nordmans, 2 ft.......... 3.50

Fir, Concolor, 18 in............. 3.00

Fir, Concolor, 2 to $21 / 2 \mathrm{ft} \ldots \ldots \ldots 5.00$

Juniper, Irish, 18 to 24 in ...... 1.25

Juniper, Douglas Golden, 15 in.. 1.50

Juniper, Virginiana, $21 / 2$ to $3 \mathrm{ft} .2 .00$

Juniper, Pfitzeriana, 18 to 24 in. 2.25

Juniper, Ffitzeriana, 2 to $3 \mathrm{ft}$... 3.75

Juniper, Sabina, 18 to 24 in.... 2.00

Juniper, Virginiana glauca, 18 to

24 in. .................. 3.00

Juniper, Stricta, 12 to 15 in.... 1.75

Pine, Austrian, 2 to $3 \mathrm{ft} . \ldots \ldots \ldots 2.50$

Pine, Austrian, 3 to $4 \mathrm{ft} . \ldots \ldots \ldots 3.50$

Pine, White, 2 to $3 \mathrm{ft} \ldots \ldots \ldots \ldots 2.50$

Pine, Mugho, 12 to 15 in ...... 2.75

Pine, Mugho, 18 in.......... 3.50

Retinospora, or Japanese Cypress.

Retinospora, Plumosa, 18 in....2 200

Retinospora, Plumosa, 2 to $3 \mathrm{ft} \ldots 3.00$

Retinospora, Plumosa urea, gold-

en, 18 in.................... 2.25

Retinospora, Plumosa a urea, goid-

en, 2 to $3 \mathrm{ft} \ldots \ldots \ldots \ldots \ldots \ldots .3 .25$

Retinospora, Squarosa, siivery, is

in. ......................... 25

Retinospora, Squarosa, silvery, 2

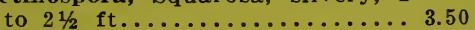

Spruce, Norway, 18 to 24 in.... 1.25

Spruce, Norway, 2 to $3 \mathrm{ft} \ldots \ldots \ldots 1.75$

Spruce, Norway, 3 to $4 \mathrm{ft} \ldots \ldots \ldots 2.25$

Spruce, Norway, 4 to $5 \mathrm{ft} \ldots \ldots .3 .00$

Spruce, Hemlock, 18 to 24 in.... 2.25

Spruce, Hemlock, 2 to $2 \frac{1 / 2}{\mathrm{ft}} \ldots \mathbf{3 . 0 0}$

Spruce, Kosters blue, 18 in........\$5.00

Spruce, Kosters blue, $2 \mathrm{ft} \ldots \ldots \ldots \ldots \ldots .6 .00$

Spruce, Kosters biue, $2 \frac{1}{12}$ ft......... 7.00

\section{HEDGE PLANTS}

Per 10
$\begin{gathered}\text { California Privet-the most } \\ \text { popular hedge plant. }\end{gathered}$

Barberry, Thunbergs, plant-

ed as hedge and singly. Each Per10 Per100 6 to 12 in..............25 $\$ 2.00 \quad \$ 15.00$ 12 to 18 in ................ $2.50 \quad 20.00$

18 to 24 in ............. 35 3.00 30.00

\section{FLOWERING SHRUBS}

All prices for Flowering Shrubs except where noted:

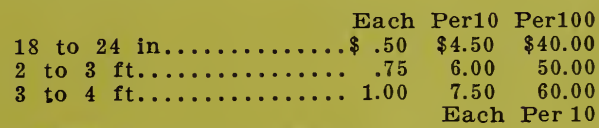

Azalea, Amoena, evergreen, 12 to

15 in. .................... \$2.50

Azalea, Mollis, large flowers, 12

to 15 in. .................... 1.50

Aithea, (Rose of Sharon).

Althea, Ardens, purplish blue, double.

Aithea, Boule de Feu, double red.

Althea, Elegantissima, double white, crimson center.

Althea, Speciosa, double pink.

Althea, Carnea Plena, double pink, crimson center.

Althea, Jean de Arc, pure white, double.

Butterfly Bush, (Buddleia Veitchi).

Barberry, Japanese.

Barberry, Purple.

Calycanthus, (Sweet Shrub).

Deutzia, Crenata.

Deutzia, Pride of Rochester.

Deutzia, Gracillis.

Dogwood. Red Stem.

Forsythia, (Golden Bells).

Hydrangea, P. G.

Hydrangea, P. G., Tree form, 3 to $4 \mathrm{ft}$. stem..........\$1.50

Hydrangea, Arborescens sterilis.

Hawthorne, double scarlet and white, 3 to $4 \mathrm{ft} . \ldots \ldots \ldots \ldots \ldots 1.50$

Honeysuckles, upright, red and white.

Kerria Japonica, (Globe Flower).

Lilacs, Comman white and purples.

Lilacs, Improved named varieties, special selected colors, 2 to $3 \mathrm{ft}$. $\quad .75$

Mock Orange.

Mahonia, Aquifolia, 18 to 24 in.. 1.5012 .50 Snowberry.

Snowball, Japanese.

Spirea, Van Houtti.

Spirea, Billardi.

Spirea, Anthony Waterer, 1 to $1 \frac{1 / 2}{2}$

ft. $\ldots \ldots \ldots \ldots \ldots \ldots \ldots \ldots . .50$

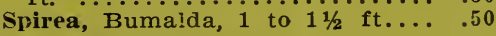

Weigela, Eva Rathke.

Weigela, Rosea. 


\section{CLIMBING VINES}

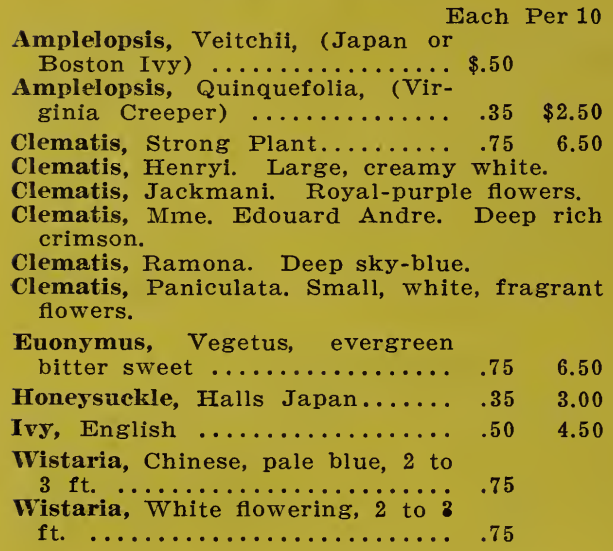

\section{HARD PERENNIAL PLANTS}

Each Per 10

Iris, German, Blue, Yellow and

White ................. \$.25 \$2.00

Iris, Japan, assorted colors..... $\quad .35 \quad 3.00$

Paeonies, Named varieties.... $\quad \begin{aligned} & \text {..75 } \\ & \mathbf{5}\end{aligned}$

Paeonies, Red, White, Pink..... .35 $\quad 3.00$

Phlox, Named varieties........ .25 2.00

\section{ROSES}

Each

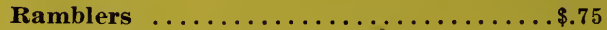

Hybrid Perpetuals .............. 80

Tea, Hybrid Tea and Everblooming Roses .80

Baby Ramblers .................... 85

In large orders send list of wants for special prices.

We urge our regular customers to place their orders with us as early as possible, so that their lists may be filled complete.

Our stock is of the usual good quality, such as we have furnished in the past. To those that never bought from us we can only say that our stock has given general satisfaction and a trial of it will prove its worth. We invite you to see our stock.

Terms Cash, except when expressly agreed otherwise.

Shipping-We have the Pennsylvania, Philadelphia \& Reading Railroads, and the Lancaster Trolley system, and can ship in any direction with the probability of prompt arrival at destination. All shipments travel at the cost and risk of the purchaser.

Guarantee-We use the greatest care possible to have our stock true to name as we beileve them to be in all instances, and should any prove not true, we stand ready to replace it free of charge or to refund the purchase price, but do not hold ourselves liable to other damages than are herein named; and all our sales are made with this understanding.

All Agreements and contracts are made subject to loss of crop by drouth, floods, fire, hail, or other unavoidable causes.

Our nurseries are inspected every year and every shipment will be accompanied by a Certificate of the State Examiner.

Location-Our office and packing grounds are situated three miles south of Manheim and one and one-half miles north of East Petersburg.

Cars on the Trolley Road from Lancaster to Manheim pass within one mile of the nursery. Visitors welcome.

Bell Phone, Landisville.

Ind. Phone, E. Petersburg. 